\title{
KOMUNIKASI DAN PENERAPAN BUDAYA KERJA ORGANISASI
}

\author{
Oleh: \\ Muslikhah Dwihartanti \\ FISE UNY
}

\section{Abstrak}

Lahirnya sebuah organisasi selalu didukung oleh tiga unsur yang saling berhubungan, yaitı manusia, kerjasama, dan tujuan bersaına. Diantara ketiganya, faktor manusia adalah yang paling penting sebagai pengolah input menjadi output yang memenuhi keinginan pasar. Agar organisasi dapat mencapai tujuan dan mampu menguasai masa depan, maka setiap Sumber Daya Manusia (SDM) harus dikondisikan sedemikian rupa sehingga mereka dapat sekerja dengan efisien.

Untuk itu di dalam organisasi diperlukan adanya program budaya kerja yang akan merubah cara kerja lama atau tradisional yang menghambat kemajuan, menjadi cara kerja baru yang lebih terbuka dan mendorong SDM untuk bekerja lebih optimal dan efisien. Pelaksanaan program budaya kerja harus didukung oleh komunikasi yang baik diantara masing-masing level dalam organisasi. Karena dengan komunikasi, adanya benteng birokrasi yang membuat SDM terkotak-kotak dapat dibuka dan dengan demikian penyebaran informasi dapat mencapai sasaran sekaligus memberi peluang untuk adanya koordinasi dan partisipasi

Pelaksanaan komunikasi harus dilakukan dengan efektif yaitu dengan meningkatkan respon serta menghindarkan pesan yang tidak jelas. Dengan demikian informasi yang disampaikan akan lebih jelas dan tidak terjadi salah tafsir.

Kata Kunci : Komunikasi, Budaya Kerja Organisasi

\section{Pendahuluan}

Secara naluri, manusia cenderung untuk hidup secara mengelompok. Dorongan manusia untuk hidup secara mengelompok tersebut disebabkan karena manusia merupakan makhluk sosial atau bermasyarakat, disamping juga karena manusia memiliki kebutuhan-kebutuhan yang tidak dapat dipenuhi sendiri. Keadaan inilah yang mendorong munculnya organisasi.

Ada beberapa pendapat mengenai deïinisi organisasi, tapi 
secara garis besar Wursanto (2002) membedakan organisasi menjadi dua macam, yaitu organisasi dalam arti statis dan organisasi dalam arti dinamis. Organisasi dalam arti statis merupakan wadah atau tempat kegiatan administrasi dan manajemen berlangsung dengan gambaran yang jelas tentang saluran hierarki kedudukan, jabatan, wewenang, dan tanggung jawab. Sedangkan organisasi dalam arti dinamis berarti melihat organisasi sebagai sesuatu yang hidup, tidak hanya dari bentuk dan wujud, tapi juga isi. Atau dengan kata lain, organisasi dalam arti dinamis berarti sekelompok manusia yang melakukan kerjasama untuk mencapai tujuan bersama.

Organisasi memiliki tiga unsur yang tidak berdiri sendiri, tapi saling berhubungan atau berkaitan sehingga menjadi satu kesatuan. Ketiga unsur tersebut adalah manusia, kerjasama, dan tujuan bersama. Dari ketiga unsur tersebut, manusia menjadi faktor yang paling penting. Menurut Wursanto (2002) hal itu disebabkan:

1. Manusia merupakan makhluk Tuhan yang paling sempurna diantara makhluk ciptaan Tuhan.

2. Manusia mempunyai rasio, berbeda dengan makhluk hidup lainnya.

3. Faktor-faktor lainnya yang dimiliki oleh organisasi hanya mempunyai arti dan bermanfaat apabila manusia mampu mengelolanya dengan baik.
4. Manusia mempunyai kemauan dan kemampuan untuk berbuat dan membangun.

5. Manusia merupakan faktor perangsang kearah tercapainya tujuan organisasi secara efisien dan efektif.

6. Manusia merupakan modal utama bagi organisasi.

7. Manusia merupakan makhluk sosial, makhluk bermasyarakat, yang mampu mengadakan kerjasama dengan semua pihak dalam usaha mencapai tujuan beisama.

8. Manusia mampu untuk berkembang, baik dalam cara berpikir, cara hidup, dan cara bermasyarakat. Makin tinggi cara berpikir dan cara hidupnya maka semakin tinggi pula tingkat peradabannya. Makin maju cara bermasyarakatnya berarti semakin tinggi kesadaran manusia untuk berorganisasi.

Berbicara mengenai organisasi memang tidak bisa lepas dari manusianya, karena manusia adalah sentrum segalanya. Atau dengan kata lain dapat dikatakan bahwa unsur manusia (SDM) dalam organisasi mempunyai kedudukan yang sangat strategis. Karena manusialah yang bisa mengetahui input-input apa yang perlu diambil dan bagaimana cara untuk mendapatkan atau menangkap input-input tersebut, teknologi dan cara apa yang dianggap tepat untuk meng- 
olah atau mentransformasikan inputinput tersebut menjadi output-output yang memenuhi keinginan pasar atau publik, sehingga organisasi dapat mencapai keberhasilan.

Dengan demikian jelas bah-wa SDM sangat penting dalam su-atu organisasi. Pertanyaannya adalah SDM yang seperti apakah yang mampu membuat sebuah organisasi hidup dan bertahan, mampu mencapai tujuan dan keberhasilan, serta mampu menghadapi tantangan masa depan? Jawabannya adalah SDM yang handal dan memiliki produktivitas kerja yang tinggi. Untuk memenuhi SDM yang demikian, maka dalam sebuah organisasi perlu melaksanakan budaya kerja, yang akan merubah sikap dan perilaku SDM untuk mencapai produktivitas kerja yang tinggi.

\section{Budaya Kerja}

Munculnya konsep budaya kerja bisa jadi berangkat dari ketidakpuasan terhadap hasil, ataupun pencapaian tujuan yang kurang memuaskan. Hal itu dipicu oleh cara bekerja para karyawan dalam organisasi, yang biasanya identik dengan birokrasi yang berbelit-belit, kurang terbuka dengan orang lain, lamban bekerja, kaku, serta kurang percaya pada kemampuan orang. Pada akhirnya sikap dan sifat tersebut mengakibatkan organisasi tidak bisa mencapai tujuan yang direncanakan, mengecewakan klien, dan tidak mampu memenuhi tuntutan kebutuhan masa depan.
Oleh karena itu apabila organisasi ingin berhasil maka perlu diadakan perubahan cara kerja baru yang lebih baik, lebih efektif dan efisien, lebih demokratis, dan lebih fleksibel dan meninggalkan cara kerja lama yang menghambat pencapaian tujuan organisasi. Perubahan cara kerja lama kepada cara kerja baru dapat dimulai dari mencari cara ataupun nilai-nilai baru, kemudian nilai-nilai tersebut dilaksanakan secara terus-menerus sambil diadakan perbaikan kearah kesempurnaan dan akhirnya menjadi kebiasaan kerja baru. Kebiasaan baru inilah yang akhirnya menjadi budaya baru yang dimiliki organisasi.

Apa yang dimaksud dengan budaya kerja? Budaya kerja adalah suatu falsafah yang cidasari oleh pandangan hidup sebagai nilai-nilai yang menjadi sifat, kebiasaan dan kekuatan pendorong, membudaya dalam kehidupan suatu kelompok masyarakat atau organisasi, kemudian tercermin dari sikap menjadi perilaku, kepercayaan, cita-cita, pendapat dan tindakan yang terwujud sebagai "kerja" atau "bekerja". Budaya kerja organisasi adalah manajemen yang meliputi pengembangan, perencanaan, produksi dan pelayanan suatu produk yang berkualitas dalam arti optimal, ekonomis, dan memuaskan (Gering Supriyadi dkk, 2001). 
Menurut Budhi Paramita (Gering Supriyadi dkk, 2001), buda-ya kerja dapat dibagi menjadi:

1. Sikap terhadap pekerjaan, ya-itu kesukaan akan kerja dibandingkan dengan kegiatan lain.

2. Perilaku pada waktu bekerja, antara lain rajin, berdedikasi, bertanggung jawab, berhati-hati, teliti, cermat, kernauan yang kuat untuk mempelajari tugas dan kewajibannya, suka mem-bantu dan sebaliknya.

Untuk mencapai budaya kerja sangat tidak mudah dan membutuhkan waktu yang lama. Mengapa? Karena mencapai atau melaksanakan budaya kerja sama artinya dengan merubah atau memperbaiki tingkah laku/perilaku karyawan dan merubah cara pandang dan cara berpikir SDM dalam organisasi tersebut. Selain itu untuk menerapkan budaya kerja, setiap SDM atau karyawan harus memahami visi dan misi organisasi, maksud dan tujuan organisasi, asas-asas yang dimiliki, serta alasan mengapa perlu diadakan atau diterapkan budaya kerja, dengan didukung oleh sikap pucuk pimpinan.

Kemudian manfaat apa yang akan diperoleh, baik oleh karyawan maupun oleh organisasi apabila melaksanakan budaya kerja? Manfaat yang dapat dipetik antara lain adalah terciptanya sikap keterbukaan, kebersamaan dan kegotongroyongan. Dengan budaya kerja yang baru, maka sikap yang semula tertutup dan tidak percaya kepada sesama rekan perlahan-lahan dapat dihilangkan. Sikap terbuka tersebut pada akhirnya mengurangi kesalahan-kesalahan kerja yang dapat berakibat fatal, karena munculnya kesalahan dapat segera diketahui dan dilakukan pembenahan. Dengan keterbukaan pula maka manipulasi data dapat dihindari karena semua bidang atau semua bagian dalam organisasi bekerja secara transparan dan dapat dipantau. Hasil yang diperoleh dari karyawan yang melaksanakan budaya kerja baru adalah pergaulan antar sesama karyawan semakin dekat, kepuasan kerja semakin meningkat, disiplin kerja bagus, dan etos kerja semakin tinggi. Hal tersebut disebabkan para karyawan merasa dihargai dan dihormati, merasa diberi kepercayaan sehingga mereka berusaha untuk lebih produktif lagi.

Selanjutnya Gering Supriyadi (2001) menyatakan lipaya penanaman nilai budaya kerja dalam manajemen dapat dilakukan melalui:

1. Struktur organisasi yang benar sesuai dengan tuntutan/tujuan dan sebagai strategi.

Struktur organisasi dibuat agar organisasi tersebut lebih konkrit dan tidak sekedar sebuah bangunan atau gedung belaka. Struktur organisasi berkaitan dengan hubungan-hubungan pekerjaan dalam organisasi yang muncul sebagai hasil dari proses pemecanan atas 
masalah-masalah: pembagian pekerjaan, departemenisasi, rentang kendali dan pendelegasian kekuasaan. Oleh karena itu struktur organisasi yang dibuat dengan benar akan menjadi strategi dalam menjawab masalah-masalah tersebut.

2. Melakukan manajemen secara horizontal, lebih banyak yang bersifat kerjasama/koordinasi.

3. Memberikan pelayanan atas dasar strategi yang baik.

Yaitu pelayanan yang memuaskan pelanggan, yang sesuai dengan dengan standart pelayanan yang dimiliki.

4. Interaksi atau pergaulan atas dasar silih asih, asah dan asuh.

5. Membuang budaya yang negatif dan memasukkan nilai-nilai baru.

Cara-cara bekerja tradisional yang kaku dan tertutup diganti dengan cara bekerja modern yang lebih terbuka dan menghargai.

6. Orientasi kerja pada peningkatan kualitas.

Jadi orientasi kerja tidak hanya semata-mata pemenuhan target jumlah tertentu, tapi juga dengan standart kualitas tertentu.

7. Mengembangkan upaya kemitraan Ipartnership.

Upaya kemitraan hanya dapat terwujud apabila masing-masing pihak memiliki kepercayaan terhadap pihak yang lain. Sehingga semakin tinggi kepercayaan, semakin baik pula kerjasama atau partnership diantara mereka.
8. Melakukan gaya kepemimpinan dengan keteladanan.

Pemimpin tidak hanya memberikan perintah-perintah yang harus dikerjakan oleh bawahan, tetapi lebih cenderung memberikan contoh, memotivasi atau memberi dorongan kepada karyawan/bawahan, serta mengajak atau meng-himbau.

9. Manajemen/administrasi dengan melakiukan penyempurnaan terus-menerus.

\section{Komunikasi}

Pelaksanaan program budaya kerja memerlukan berbagai faktor pendukung agar dapat berhasil. Salah satu faktor yang sangat mendukung dalam proses pelaksanaan program budaya kerja adalah komunikasi. Mengapa demikian? Karena dengan komunikasilah segala hal dapat diselesaikan. Komunikasi antar karyawan diperlukan dalam rangka mendukung sikap keterbukaan dan gotong royong, sementara komunikasi antara pimpinan dan karyawan diperlukan dalam rangka memberikan bimbingan dan mengakomodasi pendapat bawahan. Namun pada intinya komunikasi diperlukan untuk memperlancar penyebarar, informasi. Dengan komunikasi yang baik, maka maksud dan tujuan organisasi dapat dipahami oleh setiap bagian dalam organisasi, selain juga memunculkan kepercayaan dari setiap le- 
vel organisasi sehingga kerjasama juga akan terjalin dengan baik.

Komunikasi dalam organisasi sebenarnya merupakan satu kegiatan intern. Tetapi dalam praktek, kegiatan komunikasi dalam organisasi dapat melampaui batas organisasi itu sendiri. Oleh karena itu masalah komunikasi dalam organisasi meliputi dua segi; masalah ko-munikasi itu sendiri dan masalah organisasi (lg. Wursanto, 2003). Masalah yang timbul dalam organisasi dapat segera terselesaikan bila komunikasi yang terjadi dalam organisasi dapat berjalan dengan baik. Komunikasi dalam organisasi dapat berjalan dengan baik bila arus informasi dalam organisasi tidak mengalami hambatan. Dengan demikian komunikasi menjadi satu hal yang penting dalam organisasi. Pentingnya komunikasi dalam organisasi dapat dilihat sebagai berikut:

1. Memunculkan rasa kesetiakawanan antar karyawan/individu.

2. Meningkatkan moral disiplin.

3. Meningkatkan samangat kerja dan belajar.

4. Informasi dan keterangan-keterangan yang dibutuhkan dapat cepat diakses.

5. Meningkatkan tanggung jawab.

6. Menimbulkan toleransi atau saling pengertian.

7. Meningkatkan kerjasama.

Peran komunikasi dalam program budaya kerja adalah sebagai upaya membuka benteng-benteng birokrasi yang selama ini membuat
SDM terkotak-kotak, sehingga komunikasi menjadi terhambat. Hal itu berakibat penyebaran informasi tidak mencapai sasaran dan rnenimbulkan kesulitan dalam upaya partisipasi dan pengambilan keputusan. Dengan komunikasi yang terbuka, maka jalan menuju kerjasama dan koordinasi dalam manajemen menjadi lebih mudah, karena setiap orang tidak lagi mementingkan dirinya sendiri, rasa saling ketergantungan meningkat yang berarti tingkat kepercayaan satu dengan yang lainnya sangat tinggi (Gering Supriyadi dkk, 2001).

Apa yang dimaksud dengan komunikasi dan komunikasi yang bagaimana yang dapat mendukung program budaya kerja dalam organisasi? Komunikasi merupakan proses penyampaian pesan/informasi dan ide-ide dari satu pihak kepada pihak lain dalam rangka mencapai tujuan yang ditetapkan. Menurut A.W. Widjaja (2000) komunikasi pada umumnya diartikan sebagai hubungan atau kegiatan-kegiatan yang berkaitan dengan masalah hubungan, atau diartikan pula sebagai saling tukar-menukar pendapat. Komunikasi dapat juga diartikan hubungan kontak antar dan antara manusia, baik individu maupun kelompok.

Proses komunikasi dapat dikatakan telah terjadi bila seseorang telah melihat perilaku orang lain dan mengaitkannya dengan sebuah 
arti dalam persepsinya. Komunikasi memiliki beberapa ciri atau sifat yang perlu dipahami:

1. Terjadinya komunikasi tidak dapat dihindari. Adanya kontak sosial akan menimbulkan komunikasi.

2. Komunikasi merupakan konsep yang terus menerus.

3. Komunikasi telah terjadi bila penerima pesan atau informasi telah terpengaruh.

4. Komunikasi tidak dapat berdiri sendiri di luar konteks.

Komunikasi memiliki beberapa fungsi (A.W. Widjaja: 1986) :

1. Informasi, pengumpulan, penyimpanan, pemrosesan, penyebaran berita, data, gambar, fakta, pesan, opini, dan komentar yang dibutuhkan agar dapat dimengerti dan beraksi secara jelas terhadap kondisi lingkungan dan orang lain agar dapat mengambil keputusan yang tepat.

2. Sosialisasi (pemasyarakatan), penyediaan sumber ilmu pengetahuan yang memungkinkan orang bersikap dan bertindak sebagai anggota masyarakat yang efektif sehingga ia sadar akan fungsi sosialnya dan dapat aktif dalam masyarakat.

3. Motivasi, menjelaskan tujuan setiap masyarakat jangka pendek maupun jangka panjang, mendorong orang menentukan pilihan dan keinginannya, mendorong kegiatan individu dan kelompok berdasarkan tujuan bersama yang akan dicapai.

4. Perdebatan dan diskusi, menyediakan dan saling menukar fakta yang diperlukan untuk memungkinkan persetujuan atau menyelesaikan perbedaan pendapat mengenai masalah publik, menyediakan bukti relevan yang diperlukan untuk kepentingan umum agar masyarakat lebih melibatkan diri dengan masalah yang menyangkut kepentingan bersama.

5. Pendidikan, pengalihan ilmu pengetahuan dapat mendorong perkembangan intelektual, pembentukan watak, serta membentuk keterampilan dan kemahiran yang diperlukan pada semua bidang kehidupan.

6. Memajukan kehidupan, menyebarkan hasil kebudayaan dan seni dengan maksud melestarikan warisan masa lalu, mengembangkan kebudayaan dengan memperluas pandangan seseorang, serta membangun imajinasi dan mendorong kreativitas dan kebutuhan estetiknya.

7. Hiburan, penyebarluasan sinyal, symbol, suara dan imaji dari drama, tari, kesenian, kesusasteraan, musik, olahraga, kesenangan kelompok dan individu.

8. Integrasi, menyediakan kesempatan untuk memperoleh berbagai pesan yang diperlukan agar dapat saling kenal dan mengerti serta menghargai kondisi pandangan dan keinginan orang lain.

Sedangkan tujuan komunikasi pada umumnya adalah: 
1. Agar yang kita sampaikan dapat dimengerti dan mengikuti yang kita inginkan.

2. Memahami orang lain. Komunikator harus mengerti aspirasi masyarakat tentang apa yang diinginkan, dan bukan menginginkan kemauannya sendiri.

3. Supaya gagasan dapat. diterima orang lain. Mengusahakan agar gagasan kita diterima orang lain dan bukan memaksakan kehendak.

4. Menggerakkan orang lain untuk melakukan sesuatu. Menggerakkan dapat berupa kegiatan. Kegiatan yang dimaksud adalah kegiatan yang lebih banyak mendorong dan memahami bagaimana cara yang baik untuk melakukannya.

Komunikasi dapat berhasil bila muncul saling pengertian, yaitu jika kedua belah pihak dapat memahami informasi yang dimaksud, dan komunikasi yang baik adalah komunikasi yang efektif. Komunikasi yang efektif terjadi tidak hanya ketika seseorang mengaitkan arti tertentu terhadap perilaku orang lain, tetapi juga pada persepsi atau pandangan yang sesuai dengan maksud pemberi pesan atau informasi. Caranya adalah dengan menghindarkan pesan yang tidak jelas serta meningkatkan umpan balik. Karena dengan adanya umpan balik, situasi atau komunikasi yang tidak menentu ataupun tidak jelas akan bisa dikurangi, serta tidak menimbulkan tanda tanya antara komunikator dan komunikan. Dengan umpan balik juga akan tercipta komunikasi timbal balik dan tidak akan terjadi salah arti atau salah tafsir. Apabila komunikasi telah berjalan dengan efektif, diharapkan tercipta lingkungan yang mendukung agar nilainilai luhur dapat teraktualisasi dalam sikap dan perilaku organisasi, sehingga pelaksanaan budaya kerja organisasi dapat berhasil.

\section{Penutup}

Pada akhirnya, setiap organisasi yang ingin maju dan berkembang, mampu mencapai tujuan dan mampu bersaing di masa depan harus mampu membuang cara-cara kerja yang menghambat proses kegiatan organisasi tersebut, untuk kemudian menggantinya dengan cara-cara kerja baru yang modern dan lebih sempurna. Cara-cara kerja baru tersebut dilatih dan dibiasakan oleh seluruh bagian organisasi sehingga menjadi budaya baru yang menuntun kearah keberhasilan organisasi. Selanjutnya program budaya kerja tersebut juga harus didukung oleh komunikasi yang efektif. Karena dengan komunikasi setiap bagian dapat memahami visi, misi, dan tujuan dengan lebih jelas, memudahkan koordinasi dan kerjasama dan mencegah munculnya kesalahan-kesalahan yang dapat berakibat fatal bagi pencapaian tujuan organisasi. Dengan demikian produktivitas karyawan meningkat dan hal itu jelas menjadi 
modal penting untuk meningkatkan mutu organisasi tersebut.

\section{Daftar Isi}

A.W. Widjaja. 2000. Ilmu Komu-nikasi, Pengantar Studi .Jakarta: Rineka Cipta.

A.IN. Widjaja dan Arsyik Wahab. 1986. Komunikasi, Administrasi, Organisasi dan Manajemen dalam Pembangunan. Jakarta: Bina Aksara.

Faustino Cardoso Gomes. 1997. Manajemen Sumber Daya Manusia. Yogyakarta: Andi Offset.

Gering Supriyadi dan Triguno. 2001. Budaya Kerja Organisasi Pemerintah. LAN RI.

Wursanto, Ig. 2002. Dasar-Dasar IImu Organisasi. Yogyakarta: Andi Offset.
Biodata Penulis

Muslikah Dwi Hartanti, adalah salah satu staf pengajar pada Jurusan Pendidikan Administrasi Perkantoran Fakultas limu Sosial dan Ekonomi, Universitas Negeri Yogyakarta. 